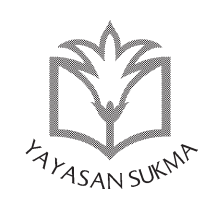

SUKMA: JURNAL PENDIDIKAN

ISSN: 2548-5105 (p), 2597-9590 (e)

Volume 2 Issue 1, Jan-Jun 2018, hlm. 121-136

https://jurnalsukma.org/index.php/sukma/article/view/02105

\title{
POLA PEMBELAJARAN AGAMA ISLAM DI MADRASAH DALAM PERSPEKTIF PENDIDIKAN HOLISTIK \\ Studi Kasus di Madrasah Aliyah Negeri 3 Sleman Yogyakarta
}

\author{
Zainal Arifin Ahmad \\ UIN Sunan Kalijaga Yogyakarta, Indonesia \\ email: zainala19@gmail.com
}

\section{Abstract}

This research aims at investigating the pattern of Islamic learning process at Yogyakarta-based Islamic senior high school-3 from holistic learning perspective. The research adopts qualitative approach. The research shows that the pattern of the Islamic learning process at the Islamic senior high school implemented in the unity of Islamic education curriculum with three main inseparable components, i.e. intra-curricular, extracurricular and hidden-curricular, has accommodated 
holistic learning principles. The accommodation can be evaluated from the implementation of basic holistic learning principles comprising of interconnectedness, wholeness and being. In spite of this accommodation, the research has found some weaknesses in the Islamic learning processs. First, the development of the fivelevel of learners potencies as envisioned in holistic learning, i.e. personal, community, social, planetary and cosmic, has not been formulated explicitly in the curriculum and lesson plan. The existing formulation only respects to the development of six dimensions of learners potencies, i.e. physical, emotional, intellectual, social, aesthetic, and spiritual. Second, the intra-curricular learning process is still more oriented to teaching for the test and less oriented to teaching for the whole task. Third, the subject matter of Islamic learning curriculum, i.e. al-Qur'an-Hadis, AkidahAkhlak, and Fikih have not been integrated as a single unit. The three subject matters still stand on their own theme, and have not been integrated as a single unit. The research has successfully mapped out the characterizing pattern of quality development of Islamic learning process seen from the perspective of holistic learning at the madrasah.

[Penelitian ini bertujuan untuk mengungkapkan pola pembelajaran agama Islam di MAN 3 Sleman Yogyakarta ditinjau dari perspektif pembelajaran holistik. Penelitian ini menggunakan pendekatan kualitatif. Hasil penelitian menunjukkan bahwa proses pembelajaran agama Islam di MAN 3 Sleman Yogyakarta yang diimplementasikan dalam kesatuan program pembelajaran intrakurikuler, ekstrakurikuler, dan hidden curricular secara umum telah mengarah kepada pola pembelajaran holistik. Dikatakan demikian karena dalam penerapan kesatuan tiga program pembelajaran tersebut ditemukan adanya penerapan tiga prinsip 
dasar pembelajaran holistik yang meliputi connectedness, wholeness, dan being. Hanya saja, dalam proses pembelajaran agama Islam tersebut masih terdapat beberapa kelemahan. Pertama, secara konseptual, pengembangan lima level potensi peserta didik (personal, komunitas, sosial, planetari, dan kosmis) sebagaimana dicanangkan dalam pembelajaran holistik belum terumuskan secara eksplisit dalam kurikulum maupun dalam perencanaan pembelajaran agama Islam. Rumusan yang ada hanya berkenaan dengan pengembangan enam dimensi potensi peserta didik (fisik, emosi, intelektual, sosial, estetika, dan spiritual). Kedua, proses pembelajaran agama Islam intrakurikuler masih lebih dominan berorientasi pada teaching for the test dan kurang berorientasi pada teaching for the whole task. Ketiga, materi pelajaran agama Islam intrakurikuler yang meliputi Akidah-Akhlak, al-Qur'anHadis, dan Fikih masih merupakan materi pelajaran yang berdiri sendiri-sendiri dan belum terintegrasi sebagai satu kesatuan untuk dapat memberikan kemampuan kepada peserta didik dalam melakukan tugas-tugas yang bersifat kompleks dan menyeluruh (whole task). Penelitian ini memberi kontribusi dalam memetakan karakteristik pola proses pembelajaran agama Islam di madrasah ditinjau dari perspektif pembelajaran holistik.]

Kata Kunci: Pembelajaran Agama Islam, Madrasah, Pendidikan Holistik

\section{A. Pendahuluan}

Proses pembelajaran merupakan ujung tombak dan inti kegiatan pendidikan (Suryosubroto 2005, vi). "Teaching is the core process through which education happens", demikian pendapat Michael J. Dunkin dan Bruce J. Biddle (Dunkin \& Biddle 
1974, 1). Karena itu dapat dipastikan bahwa efektifitas pendidikan juga tergantung pada kualitas proses pembelajaran. Hal itu diperkuat oleh pendapat Pam Sammons dkk., yang menyatakan bahwa kualitas proses pembelajaran memiliki pengaruh lebih signifikan terhadap kemajuan belajar peserta didik dibanding factor lainnya, khususnya faktor lingkungan sekolah (Sammons, et.al. 2009).

Berkaitan dengan cara mengukur efektifitas atau kualitas proses pembelajaran (efective or good teaching), Lee S. Shulman menjelaskan ada dua pendekatan (konsep) yang berbeda (contrasting conceptions of effectiveness). Pertama, konsep pragmatik atau korelatif (pragmatic or correlative conceptions of effectiveness). Kedua, konsep normatif yang diderivasi dari suatu teori atau ideologi (normative conceptions of effectiveness derived from theory or ideology) (Shulman 1986, 28). Pendekatan pertama melihat efektivitas pembelajaran dari segi process-product correlations atau hubungan antara proses pembelajaran dengan pencapaian akademik sesuai dengan ukuran-ukuran hasil pembelajaran yang telah ditetapkan, seperti skala sikap, inventori minat, dsb. Untuk mengetahui efektivitas pembelajaran harus dilakukan uji korelasi antara proses dan hasil (Shulman 1986, 28). Sedangkan pendekatan kedua, yakni normatif, melihat efektivitas pembelajaran dari sisi korespondensi (keterkaitan/kesesuaian) pelaksanaan pembelajaran dengan model atau konsep pembelajaran ideal yang didasarkan pada teori-teori atau ideologi tertentu yang dijadikan acuan (Shulman 1986, 28).

Penelitian ini berusaha memetakan pola pembelajaran agama Islam di Madrasah Aliyah Negeri 3 Sleman Yogyakarta dengan menggunakan pendekatan normatif, yakni mengkaji proses pembelajaran agama Islam dari perspektif teori pendidikan holistik. Penggunaan teori pendidikan holistik untuk memetakan pola pembelajaran agama Islam di madrasah ini didasarkan pada alasan bahwa pendidikan holistik merupakan model pendidikan yang mampu melihat masalah pendidikan secara menyeluruh dan berorientasi pada pengembangan potensi peserta didik secara utuh. Lebih dari itu, pendidikan holistik 
merupakan model pendidikan mutakhir yang akhir-akhir ini semakin menjadi trend pendidikan abad ke 21 di berbagai belahan dunia. Para ahli di berbagai negara yang tidak puas dengan pola pembelajaran abad ke 19 yang bersifat reduksionis, juga mulai mengembangkan pola-pola pendidikan holistik. Ujicoba-ujicoba efektifitas pembelajaran yang menggunakan pendekatan holistik juga mulai banyak dilakukan. Eksperimen pendidikan holistik, sebagaimana dilakukan oleh Nandish V. Patel (2003, 2-3) maupun Paul Kirschner dan Jeroen J.G. van Merriënboer (2011), misalnya, secara empirik telah terbukti efektifnya dalam membangun kebermaknaan pembelajaran bagi peserta didik dan lingkungan.

Penelitian ini dipandang penting karena berdasarkan telaah pustaka yang ada penelitian tentang proses pembelajaran agama Islam di madrasah dari perspektif pendidikan holistik belum dilakukan oleh peneliti lain. Beberapa penelitian tentang pendidikan agama Islam di madrasah lebih melihat dari aspek kurikulum dan implementasinya. Salamah, misalnya, melakukan penelitian tentang Pengembangan Kurikulum Holistik Pendidikan Agama Islam pada Madrasah Tsanawiyah untuk meningkatkan hasil belajar. Karena fokus utama penelitian Salamah kurikulum, maka pembahasan mengenai proses pembelajaran agama Islam hanya bersifat tambahan (Salamah 2006). Penelitian lainnya dilakukan oleh Siti Nur Rochmah Azwarini. Siti melakukan penelitian evaluatif terhadap implementasi kurikulum PAI Berbasis Kompetensi (Azwarini 2005). Penelitian Azwarini ini masih terbatas pada pembelajaran yang terjadi di kelas dan belum mencakup keseluruhan proses yang terjadi di madrasah yang mencakup pembelajaran di dalam kelas maupun di luar kelas. Sementara M. Husen Madhal melakukan penelitian dengan judul "Sistem Pendidikan Nilai Agama dalam belajar-mengajar di Madrasah Aliyah Wakhid Hasyim Gaten Sleman Yogyakarta Tinjauan Faktor Guru dalam interaksi edukatif". Penelitian ini lebih melihat aspek interaksi edukatif antara guru dan peserta didik (Madhal 2003).

Penelitian ini menggunakan pendekatan kualitatif. Teknik pengumpulan data menggunakan observasi, wawancara, dan dokumentasi. 
Teknik analisis data menggunakan dua corak analisis. Pertama, analisis saat mempertajam keabsahan data melalui "simultaneous cross sectional", dan kedua, melalui interpretasi data secara keseluruhan. Berdasarkan data yang diperoleh, dikembangkan penajaman data melalui pencarian data selanjutnya. Dalam penelitian ini, data tidak dianggap sebagai error reality yang dipersalahkan oleh teori yang ada sebelumnya, tapi dianggap sebagai another reality. Berdasarkan hal tersebut, data yang didapat merupakan data langsung dari tangan pertama, tanpa melalui tes atau angket yang pada gilirannya hal tersebut justru membuat jarak dengan sumber data (Nasution 1988, 9-10).

\section{B. Pengertian Pendidikan Holistik}

Ron Miller, pendiri The Journal Holistic Education Review dan penggiat pendidikan holistik menjelaskan:

Holistic education is a philosophy of education based on the premise that each person finds identity, meaning, and purpose in life through connections to the community, to the natural world, and to spiritual values such as compassion and peace. (Miller 2007).

Berdasarkan premis bahwa setiap individu memiliki potensi untuk dapat menemukan jati diri, makna dan tujuan hidup yang sejati, maka pendidikan holistik berusaha membangkitkan seluruh potensi yang dimiliki individu secara intrinsik. Pendidikan holistik berupaya membangun secara utuh dan seimbang seluruh potensi individu yang mencakup spiritual, moral, imajinatif, intelektual, budaya, estetika, emosi dan fisik yang mengarahkan seluruh aspek-aspek tersebut ke arah pencapaian sebuah kesadaran tentang hubungannya dengan Tuhan yang merupakan tujuan akhir semua kehidupan di dunia (Rubiyanto \& Haryanto 2010, 192).

Model pendidikan holistik ini berbeda dari pembelajaran lainnya, misalnya pembelajaran behavioristik. Menurut teori behaviorisme, setiap individu akan mengalami proses belajar 
(respon) jika ada stimulus. Semakin kuat stimulus (reinforcement) maka semakin kuat terjadinya proses belajar. Penguatan stimulus antara lain berupa pengkondisian lingkungan dan pembiasaan atau disiplin (Budiningsih 2005, 20). Berdasarkan premis ini, pembelajaran behavioristik lebih mementingkan pemberian stimulus dari pada pengembangan potensi intrinsik peserta didik. Sedangkan pendidikan holistik lebih mementingkan pengembangan potensi intrinsik peserta didik secara utuh tanpa mengabaikan arti penting stimulus berupa lingkungan, baik lingkungan sosial maupun alam.

Berdasarkan uraian di atas dapat disimpulkan bahwa pendidikan holistik adalah pembelajaran yang didasarkan pada premis bahwa setiap individu memiliki potensi untuk dapat menemukan jati diri, makna dan tujuan hidup yang sejati. Dengan premis tersebut pendidikan holistik berusaha membangun dan membangkitkan semaksimal mungkin seluruh potensi yang dimiliki individu secara intrinsik, utuh dan seimbang yang mencakup fisik, emosi, intelektual, sosial, estetika, dan spiritual yang kesemuanya diarahkan kepada pencapaian sebuah kesadaran tentang hubungannya dengan sesama manusia, alam, dan Tuhan yang merupakan sumber dan tujuan akhir semua kehidupan.

\section{Prinsip-prinsip Pendidikan Holistik}

Prinsip-prinsip pendidikan holistik, sebagaimana dimuat dalam situs www.hent.org/hent/fundamental.htm., meliputi tiga prinsip dasar, yaitu keterhubungan (connectedness), menyeluruh (wholeness) dan menjadi (being). Prinsip keterhubungan merupakan konsep yang berasal dari filsafat holism mengenai keterhubungan realitas yang dikembangkan lebih lanjut dalam teori ekologi, fisika quantum dan teori sistem.

Prinsip keterhubungan (connectedness) meliputi:

1) Interdependence (saling tergantung), yaitu bahwa fungsi bagian bergantung erat dengan bagian dan sistem lain secara keseluruhan.

2) Interrelationship (saling berhubungan), yaitu bahwa terdapat 
hubungan jaringan yang kompleks di antara bagian sistem dengan sistem lain.

3) Participatory (keterlibatan), yakni bahwa setiap pengamat selalu terkait erat dengan lingkungannya dalam memahami realitas yang diamati.

4) Non-linearity (tidak linear), yaitu bahwa pola interaksi yang kompleks terjadi lebih umum (more common) dari pada pola interaksi sebab-akibat yang bersifat linear.

Prinsip wholeness (menyeluruh) mengandung arti bahwa keseluruhan tidak sekadar kumpulan bagian. Sehingga memahami sistem tidak bisa hanya dengan mengkaji komponenkomponen secara terpisah. Prinsip ini meliputi:

1) Whole systems (sistem menyeluruh), yakni bahwa berpikir tentang sistem secara keseluruhan berarti terjadi pergeseran perhatian dari bagian ke keseluruhan, dari obyek ke hubungan, dari struktur ke proses, dan dari hirarki ke jaringan. Pergeseran ini juga mencakup pergeseran penekanan cara berpikir dari rasional ke intuitif, dari analisis ke sintesis, dan dari cara berpikir linear ke non-linear.

2) Multiple perspectives (multi perspektif), yaitu bahwa sistem yang kompleks berinteraksi dengan cara yang kompleks pula dan dapat dilihat dari banyak sudut pandang yang berbeda. Tidak ada jawaban yang bersifat "tunggal".

3) Independence, yaitu bahwa sistem dapat beroperasi dalam keseluruhan secara bebas (otonom) dan membentuk pola keseimbangan dengan lingkungan.

4) Multiple levels (multi level), yaitu bahwa suatu sistem sering mencakup jaringan sub-sistem yang berinteraksi dengan cara yang kompleks.

Prinsip menjadi (being) berkaitan dengan masalah mengalami kejadian masa sekarang. Hal ini mencakup masalah kedamaian dalam diri (inner peace), kebijaksanaan dan pemahaman, kejujuran dan otentisitas. Human beings are not limited to sensory perception or rational analysis. Being fully human is also 
Pola Pembelajaran Agama Islam di Madrasah

$\overline{\text { about using intuition, inspiration and wisdom while meeting needs }}$ for self-actualisation and self-transcendence.

Prinsip ini mencakup hal-hal sebagai berikut:

1) Fully human (benar-benar manusiawi), yaitu mengenali dimensi fisik, emosi, mental dan spiritual manusia.

2) Creative expression (ekspresi kreatif), yakni memahami pentingnya peluang berekspresi secara kreatif bagi tiap individu dan masyarakat.

3) Growth (pertumbuhan), yakni transformasi dan pertumbuhan mengijinkan setiap orang untuk mencapai aspirasi-aspirasi tertinggi dari spirit manusia.

4) Responsibility (tanggung jawab), yakni setiap individu dan kelompok memiliki tanggung jawab terhadap pilihan dan perbuatan, baik pada tingkat lokal, global maupun level kosmik.

\section{Pola Pembelajaran Agama Islam dilihat dari Prinsip Keterhubungan}

Prinsip keterhubungan (connectedness) yang meliputi prinsip interdependence (saling tergantung), interrelationship (saling berhubungan), participatory (keterlibatan), dan nonlinearity (tidak linear) dapat ditemukan secara empirik dalam sistem dan proses pembelajaran agama Islam di MAN 3 Sleman Yogyakarta.

Prinsip interdependence (saling tergantung) dalam arti bahwa fungsi bagian bergantung erat dengan bagian dan sistem lain secara keseluruhan telah diterapkan oleh para guru dalam proses pembelajaran agama Islam. Di MAN 3 Sleman Yogyakarta, pembelajaran agama Islam didesain dan diimplementasikan sedemikian rupa sehingga tidak hanya tergantung kepada salah satu pihak, misalnya hanya kepada guru agama Islam. Pembelajaran agama Islam di MAN 3 Sleman Yogyakarta melibatkan banyak pihak dan banyak aspek sebagai satu kesatuan.

Selain para guru agama Islam sebagai pihak yang paling 
bertanggung jawab, proses pembelajaran agama Islam juga melibatkan banyakpihak,yaitu semuaguru, pimpinan, karyawan, orang tua, tokoh-tokoh masyarakat, dan masyarakat pada umumnya. Di MAN 3 Sleman Yogyakarta dikembangkan 3 (tiga) jenis kurikulum, yaitu kurikulum formal, ekstra kurikulum, dan kurikulum tersembunyi (hidden curriculum). Desain dan implementasi kurikulum formal agama Islam menjadi tanggung jawab utama para guru agama Islam. Sedangkan desain dan implementasi kurikulum ekstra dan kurikulum tersembunyi melibatkan semua pihak yang terkait. Semua guru turut mengajar dan mendampingi siswa dalam kegiatan ekstra kurikuler agama Islam, seperti tadarus, latihan iqra, praktik ibadah, dzikir bersama, salat dluha dan dluhur bersama di madrasah, khutbah jum'at, dan lain-lain, termasuk dalam kegiatan sekolah kerja nyata (SKN) agama di desa-desa di setiap bulan Ramadhan. Para tokoh masyarakat dan orang tua secara berkala diundang ke madrasah untuk berdialog dan bermusyawarah untuk mengembangkan kepribadian peserta didik, khususnya dalam pengamalan nilai-nilai agama. Atas kesadaran terhadap prinsip saling ketergantungan itulah MAN 3 Sleman Yogyakarta mengembangkan pola pembelajaran agama Islam tidak terbatas pada proses pembelajaran formal di kelas, tetapi juga di luar kelas dan melibatkan banyak pihak.

Prinsip interrelationship (saling berhubungan), dalam arti bahwa terdapat hubungan jaringan yang kompleks di antara bagian sistem dengan sistem lain, memiliki verifikasi empirik dalam proses pembelajaran agama Islam. Di MAN 3 Sleman Yogyakarta, pembelajaran agama Islam didesain dan diimplementasikan dalam suatu sistem yang utuh dan saling berhubungan. Antara kurikulum formal, kurikulum ekstra, dan kurikulum tersembunyi memiliki kaitan erat dalam proses pembelajaran agama Islam. Antara tujuan ranah kognitif, afektif, dan psikomotor juga saling terkait. Demikian pula, antara komponen tujuan, materi, media, strategi, evaluasi dan langkah-langkah pembelajaran agama Islam. Interrelationship antara pihak-pihak yang terkait, seperti guru-guru agama, guru-guru non-agama, karyawan, pimpinan, orang tua, tokoh-tokoh masyarakat dan 
masyarakat secara umum juga tampak nyata dalam proses pembelajaran agama Islam di MAN 3 Sleman Yogyakarta.

Prinsip participatory (keterlibatan), dalam arti bahwa semua pihak yang berkepentingan dengan pengembangan kualitas proses pembelajaran agama Islam di MAN 3 Sleman Yogyakarta benar-benar diberi kesadaran dan dilibatkan untuk menangani proses pembelajaran agama Islam.

Sedangkan prinsip non-linearity (tidak linear), dalam arti bahwa pola interaksi dalam proses pembelajaran agama Islam yang bersifat kompleks dan tidak linear juga dapat ditemukan di MAN 3 Sleman Yogyakarta. Para guru senantiasa menjalin interaksi dengan para peserta didik bukan hanya di dalam kelas, tetapi juga di luar kelas. Para guru senantiasa membuka diri kepada para peserta didik untuk menampung keluhan-keluhan dan problem-problem yang dihadapi untuk selanjutnya membantu mencarikan solusi terbaik.

\section{E. Pola Pembelajaran Agama Islam dilihat dari Prinsip Menyeluruh (Wholeness)}

Prinsip wholeness (menyeluruh) mengandung arti bahwa keseluruhan tidak sekadar kumpulan bagian yang tidak saling terkait. Sehingga memahami sistem tidak bisa hanya dengan mengkaji komponen-komponen secara terpisah. Prinsip ini meliputi prinsip-prinsip whole systems (sistem menyeluruh), multiple perspectives (multi perspektif), independence (otonom), dan multiple levels (multi level).

Di MAN 3 Sleman Yogyakarta keseluruhan unsur kepribadian peserta didik, baik menyangkut ranah kognitif, afektif, maupun psikomotor atau aspek hardskill maupun softskill mendapat perhatian serius. Di MAN 3 Sleman Yogyakarta, dalam konteks pembelajaran agama Islam, para peserta didik tidak hanya mendapat pelajaran agama Islam secara formal di kelas yang meliputi materi Akidah-Akhlak, Qur'an-Hadits, Fiqh, dan Sejarah Kebudayaan Islam secara kognitif, tetapi juga mendapat pelatihan-pelatihan baca tulis al-Qur'an, pelatihan ibadah praktis, 
pelatihan kepemimpinan (bidang keagamaan, seperti menjadi khatib salat Jum'at, penceramah kuliah tujuah menit, dan penggerak kegiatan keagamaan di masyarakat), serta pelatihan emotional and spiritual quotient. Proses pembelajaran tersebut juga didukung oleh lingkungan yang kondusif, baik lingkungan fisik, psikis, maupun sosial. Keseluruhan komponen pembelajaran agama Islam di MAN 3 Sleman Yogyakarta tampak sebagai jaringan yang saling terkait secara kokoh.

Prinsip multiple perspectives (multi perspektif) dalam arti bahwa sistem senantiasa berinteraksi secara kompleks dan dapat dilihat dari banyak sudut pandang yang berbeda telah diterapkan dalam proses pembelajaran agama Islam di MAN 3 Sleman Yogyakarta. Para guru dalam menghadapi para peserta didik yang berperilaku negatif tidak serta merta menilai mereka sebagai anak nakal yang harus dihukum. Tetapi mereka lebih dahulu memahami latar belakang dan kondisi peserta didik secara obyektif, baik menyangkut kondisi latar belakang keluarga, latar belakang pendidikan maupun kondisi psikologisnya. Oleh karena itu, para guru dalam memberikan bimbingan kepada para peserta didik lebih mengedepankan cara persuasif daripada otoriter. Pendapat dan pandangan peserta didik bagaimanapun bentuknya juga dihargai. Dalam proses pembelajaran agama Islam di kelas, para guru senantiasa memberi kesempatan para siswa untuk mengajukan pendapat secara bebas.

Prinsip independence (independen) yang mengandung arti adanya kebebasan bagi individu atau sistem dalam berperilaku dalam rangka membentuk pola keseimbangan dengan lingkungan juga mendapat perhatian dalam proses pembelajaran agama Islam. Di MAN 3 Sleman Yogyakarta, para peserta didik dibebaskan untuk mengikuti madzhab-madzhab agama atau organisasi keagamaan yang ada. MAN 3 Sleman Yogyakarta tidak memaksakan suatu aliran atau madhab tertentu. Ketika ada upaya pihak-pihak tertentu untuk melakukan indoktrinasi terhadap paham keagamaan tertentu yang cenderung ekstrim, maka para guru segera melakukan tindakan pencegahan dan melakukan upaya netralisasi. 
Prinsip multiple levels (multi level) dalam arti adanya kesadaran bahwa suatu sistem sering mencakup jaringan sub-sistem yang berinteraksi dengan cara yang kompleks juga dapat ditemukan dalam proses pembelajaran agama Islam. Di MAN 3 Sleman Yogyakarta, proses pembelajaran agama Islam membentuk suatu sistem yang terdiri dari sub-sistem sub-sistem yang kompleks. Ada sub-sistem guru, karyawan dan pimpinan madrasah, subsistem peserta didik, sub-sistem orang tua/wali peserta didik, dan sub-sistem masyarakat. Kesadaran itu membentuk pola pembelajaran agama Islam yang integratif, di mana semua subsistem diarahkan untuk dapat mendukung tercapainya tujuan pembelajaran agama Islam.

\section{F. Pola Pembelajaran Agama Islam dilihat dari Prinsip Being}

Di MAN 3 Sleman Yogyakarta, para peserta didik diperlakukan secara manusiawi. Para guru memiliki prinsip bahwa para peserta didik harus dianggap seperti anak kandung sendiri. Para guru juga sering memanggil para peserta didik dengan ungkapanungkapan kasih sayang. Kata-kata "halo sayang" (dalam konotasi kasih sayang orang tua dengan anak) sudah biasa diucapkan guru ketika berjumpa dengan peserta didik di luar kelas. Para guru juga melakukan diskriminasi terhadap para peserta didik. Semua diperlakukan sama sesuai hak-hak mereka. Dengan pola interaksi semacam itu, para peserta didik merasa aman dan nyaman berada dalam madrasah dan dalam mengikuti proses pembelajaran agama Islam.

Selain itu, prinsip memberikan kebebasan berekspresi secara kratif juga mendapat perhatian. Para peserta didik diberi sarana menulis di majalah dinding untuk mengekspresikan gagasan-gagasannya, menjadi penceramah kultum (kuliah tujuh menit) secara bergiliran di setiap kelas, menjadi pengurus organisasi kerohaniahan siswa, menyelenggarakan kegiatan-kegiatan soisal keagamaan dan pengabdian kepada masyarakat melalui program Sekolah Kerja Nyata (SKN). 
Dengan pola pembelajaran yang sesuai dengan prinsip being, MAN 3 Sleman Yogyakarta telah melakukan upaya menumbuhkembangkan potensi siswa secara optimal sesuai dengan bakat masing-masing dan menjadi pribadi yang jujur dan bertanggungjawab, baik dalam hubungan dengan Tuhan, sesama manusia, maupun lingkungan alam.

\section{G. Kesimpulan}

Hasil penelitian menunjukkan bahwa proses pembelajaran agama Islam di MAN 3 Sleman Yogyakarta pada umumnya telah sesuai dengan prinsip-prinsip pendidikan holistik. Temuan ini menjadi menarik mengingat bahwa lembaga pendidikan madrasah yang berada di bawah naungan Kementerian Agama yang umumnya mengalami ketertinggalan dalam berbagai bidang dibanding dengan sekolah-sekolah umum di bawah pembinaan Kementerian Pendidikan dan Kebudayaan, ternyata telah mampu mengembangkan kualitas proses pembelajaran agama Islam sesuai dengan prinsip-prinsip pembelajaran yang mutakhir seperti pendidikan holistik.

Penelitian ini juga menemukan bahwa proses pembelajaran agama Islam di MAN 3 Sleman Yogyakarta telah mampu melakukan inovasi-inovasi kreatif. Keterbatasan jumlah jam pelajaran agama yang hanya sekitar 30\% dari jumlah jam pelajaran yang ada dalam kurikulum, ternyata mampu diatasi dengan baik. Oleh karena itu, menimpakan penyebab carut marut perilaku individu dan masyarakat yang tidak sejalan dengan nilai-nilai agama kepada lembaga-lembaga pendidikan merupakan sikap yang kurang adil. Paling tidak untuk kasus di MAN 3 Sleman Yogyakarta. Lebih dari itu, upaya mengatasi persoalan patologi sosial seharusnya lebih diarahkan kepada pembenahan pranata sosial yang kurang adil di luar lembaga pendidikan yang diduga kuat sebagai penyebab utama terjadinya problem sosial. 


\section{BIBLIOGRAFI}

Azwarini, Siti Nur Rochmah. 2005. "Evaluasi Implementasi Kurikulum Pendidikan Agama Islam Berbasis Kompetensi di Madrasah Aliyah Negeri Yogyakarta III." Tesis. Yogyakarta: PPS Program Magister Studi Islam Universitas Muhammadiyah Yogyakarta.

Budiningsih, C. Asri. 2004. Pembelajaran Moral Berpijak pada Karakteristik Siswa dan Budayanya. Jakarta: PT Rineka Cipta.

Departemen Agama RI Direktorat Jenderal Kelembagaan Agama

Islam Direktorat Madrasah dan Pendidikan Agama Islam

Pada Sekolah Umum, 2003. Kurikulum Berbasis Kompetensi

Pendidikan Agama Islam Madrasah Aliyah. Jakarta.

----. 2004. Kurikulum Berbasis Kompetensi Madrasah Aliyah. Jakarta. Depdiknas. 2003. Kurikulum 2004 Standar Kompetensi Pendidikan Agama Islam Sekolah Menengah Atas dan Madrasah Aliyah. Jakarta: Pusat Kurikulum Balitbang Depdiknas.

Dokumen Sejarah MAN 3 Sleman Yogyakarta tahun 2004.

Dunkin, Michael J., Bruce J. Biddle. 1974. The Study of Teaching. New York: Holt, Rinehart and Winston, Inc.

Madhal, M. Husen. 2003. "Sistem Pendidikan Nilai Agama dalam belajar-mengajar di Madrasah Aliyah Wakhid Hasyim Gaten Sleman Yogyakarta Tinjauan Faktor Guru dalam interaksi edukatif." Tesis Magister Pendidikan. Yogyakarta: Program Pascasarjana Universitas Negeri Yogyakarta.

Miller, John P. 2007. Humanizing the Classsroom. America: Praeger Publisher Inc.

Nasution, S. 1988. Metode Penelitian Naturalistik Kualitatif. Bandung: Tarsito.

Patel, Nandish V. "A Holistic Approach to Learning and Teaching Interaction: Factors in the Development of Critical Learners." The International Journal of Educational Management 17 (6/7): 272-284. http://cw.routledge.com/textbooks/0415332168/ pdf/article.pdf.

Shulman, Lee S. 1986. "Paradigms and Research Programs in 
the Study of Teaching: A Contemporary Perspective." Dalam Merlin C. Wittrock (ed.). Handbook of Research on Teaching. London: Macmillan Publishing Company. 